DOI: $10.20472 / B M .2019 .7 .2 .001$

\title{
SHARIA FINANCIAL INCLUSION SOLUTIONS AND STRATEGIES : CASE OF MSE-BMT IN NORTH SUMATERA-INDONESIA
}

\author{
RIZAL AGUS, RAHMAT WIDIA, ENNY SEGARAHATI
}

\begin{abstract}
:
Micro Small Entreprises (MSE) has a strategic role in Indonesia, but for its development still faces various complex obstacles. This study examines efforts to increase Islamic financial inclusion at UMK-BMT in North Sumatra, by conducting in-depth interviews with 3 experts from BMT in Medan City and Deli Serdang Regency, North Sumatra. Organizing FGDs on 3 expert participants and 4 MSE partners, then distributing questionnaires to these 7 people. The Analysis is carried out with a qualitative-quantitative research approach using the ANP method. This study found that what needed to be done as a solution and strategy were, the main internal solution was to improve MSE's $H R$, followed by solutions to improve MSE's performance, the solution to improve HR's main was a solution to improve expertise, followed by solutions to improve character, solutions to improve the performance of MSE's main is a solution to increase sales turnover, then a solution to increase profits, the main external solution is the BMT capital solution followed by the government solution and the motive solution for using digital media for MSE's -BMT. The main BMT capital solution is a solution to increase the use of WA followed by a solution to increase the use of internet access, Motive Solution for the Use of Digital Digital Media is a solution to increase access capability followed by a solution to increase effectiveness, a solution to increase affordability, a solution to increase security, a solution to increase flexibility and a solution to increase efficiency, Government Solutions The main solution is to improve training and solution to improve facilities. The main strategy in determining solutions and strategies agreed by all respondents is to increase training followed by government subsidy facilities, skills improvement, character building.
\end{abstract}

\section{Keywords:}

Solutions and Strategies, Islamic Financial Inclusion, MSE performance, ANP

JEL Classification: G21

\section{Authors:}

RIZAL AGUS, Politeknik Negeri Medan, Indonesia, Email: rzanst@yahoo.co.id RAHMAT WIDIA, Politeknik Negeri Medan, Indonesia, Email: rahmatws@polmed.ac.id ENNY SEGARAHATI, Politeknik Negeri Medan, Indonesia, Email: ennypolmed@gmail.com

\section{Citation:}

RIZAL AGUS, RAHMAT WIDIA, ENNY SEGARAHATI (2019). Sharia Financial Inclusion Solutions and Strategies : Case of Mse-Bmt In North Sumatera-Indonesia. International Journal of Business and Management, Vol. VII(2), pp. 1-11., 10.20472/BM.2019.7.2.001 
Based on the results analysis, the Economic Census (SE2016) in the Continued Potential for Improving Micro Small Business Performance ${ }^{1}$, explains that the first general development policy direction for 20152019 is to promote inclusive and sustainable economic growth. One way to achieve this is by increasing the competitiveness and role of micro, small and medium enterprises (MSMEs). SE2016 explained, the number of MSEs in Indonesia was 26.26 million or had a contribution of 98.33 percent. that is, analyzing the performance of MSEs in Indonesia is interesting. IP-ICT (Information and Communication Technology Development Index) is a standard measure of the level of ICT development in a region, digital divide, and the potential for ICT development. based on 11 indicators. If the index is higher, it means that the potential and progress of ICT development is more optimum, and vice versa.

In 2016, the Indonesian IP-ICT was 4.34 on a scale of $0-10$, an increase from 2015 of 3.88. From 176 countries, Indonesia's position has increased from rank 114 (2015) to 111 (2016), including in the top 10 most dynamic countries to increase the value of IP-ICT'. 11 IP-ICT indicators are organized into 3 subindexes composing the IP-ICT, namely the access and infrastructure sub-index, the use sub-index, and the expertise sub-index. The highest subindex value was the expertise subindex at 5.54 , followed by the access and infrastructure subindex at 4.88 and the usage subindex at $3.19 .^{3}$

In line with this, the Cooperative is required to adapt to this era. Kemenkop's efforts to encourage cooperatives, namely through total cooperative reforms, include reorientation, rehabilitation and development, encouraging cooperatives to grow and develop. BMT is a microfinance institution with a financial inclusion program. ${ }^{4}$

Santoso et.al., (2016) ${ }^{5}$, examining the determinants of the level of financial literacy and financial inclusion of the poor in a region of Indonesia with a sample of 970 households with financial limitations, found that lower levels of financial literacy and inclusion were strongly correlated with less educated and older people. In addition, those who live in rural areas are less financially literate than urban people.

Based on a telephone interview to the North Sumatra BMT secretary, Yusman (August 12, 2019), it was explained that the assets owned by the BMT currently amount to Rp.780,000,000, - with the number of MSEs served by 573 SMEs, through murabahah, mudharabah and musyarokah financing products. , While the qordul hasan is Rp. $80,000,000$.

While BMT S001, located in the village of Bandar Setia, Deli Serdang, North Sumatra, has also utilized IT that can be accessed via the internet, so KSPPS BMT Amanah Joint Business located on JI Puri, Medan, with assets of Rp.800,000,000, has internet access and WA to communicate with partners, but the use of IT is still limited, it has not been able to accelerate the transaction process that can be done by SMEs in an effort to improve their performance.

The media used in dealing with more partners is still in a face-to-face manner, but to make monthly financing installments already communicate digitally using WA or SMS, this is due to limited human resources. The Cooperative Office has occasionally conducted socialization about the importance of using IT in the current 4.0 industry era for MSEs.

The problems faced by BMT above relate to MSE partners, namely the low quality of human resources, the lack of training frequency, training facilitation and the still low digitalization, so that the utilization of digital facilities for financial literacy is still limited.

Many studies have been conducted relating to the issue of the use of digital facilities in carrying out Islamic financial literacy. Zulkhibri, $(2016)^{6}$, examining the relationship between financial inclusion and the Islamic financial services industry, found that most Muslim countries lag behind developing economies with a financial inclusion rate of only $27 \%$. Cost, distance, documentation, beliefs, and religious requirements are some important obstacles.

\footnotetext{
${ }^{1}$ Publikasi BPS Nomor : 07310.1901 , Dirilis : 2019

2 Internatonal Telecommunicaton Union, dalam Measuring Informaton Society Report 2017

${ }^{3}$ BPS, 2017

${ }^{4}$ https://www.kemenkeu.go.id, 10, September 2019.

${ }^{5}$ Santoso et.al., (2016), Determinants of Financial Literacy and Financial Inclusion Disparity Within a Region: Evidence from Indonesia, American Scientific Publishers, Volume 22, Numbers 5-6, May 2016, pp. 1622-1624(3)
}

6 Zulkhibri, Muhamed, (2016), Financial inclusion, financial inclusion policy and Islamicfinance, Macroeconomics \& Finance in

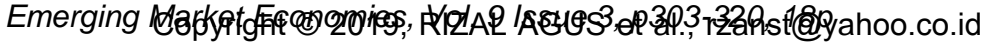




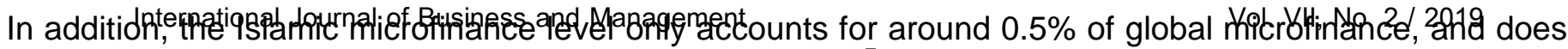
not have a cost-efficient service model. Sundaram $(2019)^{7}$, found that computers and smartphones have advantages in terms of security. Technological security does not depend on this device. Instead the responsibility rests with users, service providers and financial institutions (banks), (Maulana, et.al., 2018) ${ }^{8}$, revealing that among the three main beliefs, only behavioral control on BMT was found to have a positive and significant impact on client participation against BMT. From the description above it can be seen that the previous researchers examined by looking at the relationship between several variables. This study uses multi variable decision making through the Analitic Network Process (ANP) to find out Solutions and Effective Strategies for Sharia Financial Inclusion at MSE-BMT in North Sumatra ".

\section{Literature Review \\ Financial Inclusive}

Namely the availability of access to various institutions, products and financial services according to the needs and abilities of the community to improve their welfare. ${ }^{9}$

\section{SME Performance}

Business performance is the company's performance as measured by the acquisition of Return on Investment (ROI) and market share. Rangkuti Freddy $(2001)^{10}$, said the percentage of profits reflects the efficiency of the company in producing each unit of production, sales performance is a complex construct for a company

\section{Relationship of Human Resources Capability on SMEs}

Ahmad S. and Yohana K. S. (2013) explained that Human Resources significantly influenced the performance of MSMEs. ${ }^{11}$ Hery H. and Domy C.D. (2012) ${ }^{12}$, financial and HR aspects significantly influence the performance of MSMEs. Human resource management has several main objectives, including to improve productivity and quality of work life. ${ }^{13}$

\section{Digitalization of BMT in increasing Sharia Financial Literacy for MSEs}

The second National Literacy and Financial Inclusion Survey (SNLIK) conducted by OJK, 2016, showed that the financial literacy index was $29.66 \%$ and the financial inclusion index was $67.82 \%{ }^{14}$, while Islamic financial inclusion in Indonesia was 11 percent. $^{15}$

In connection with the above, the existence of financial technology for the people of Indonesia is now getting better, marked by the increasing use of financial technology every year, so that it becomes a necessity for people who have high mobility.

The industrial revolution towards the information technology revolution will give an overview of the character of BMT in the future. In 2017 many BMTs have innovated by making application-based transaction services, so far they have followed the development of banking technology such as ATM card services and integrated savings accounts, but have not been able to do what banks have done with large-scale financial information technology systems.

Technology uses a level of automation that requires a large investment value and is not yet reached by BMT. ${ }^{16}$

\section{BMT Capital}

\footnotetext{
${ }^{7}$ Sundaram, Jan2019, A Review: Customers Online Security on Usage of Banking Technologies in Smartphones and Computers, Pertanika Journal of Science \& Technology; Vol. 27 Issue 1, p1-31, 31p

8 Maulana, et.al., (2018), Factors influencing behaviour to participate in Islamicmicrofinance, International Journal of Islamic \& Middle Eastern Finance \& Management; Vol. 11 Issue 1, p109-130, 22p

${ }^{9}$ POJK, 76 /07/2016

${ }^{10}$ Rangkuti Freddy, Business Plan, Teknik Membuat an Bisnis \& Analisis Kasus, (Jakarta: PT.Gramedia Pustaka Utama, 2001)

${ }^{11}$ Ahmad dan Yohana (2012), "Pengaruh Kompetensi SDM, Kualitas Informasi Keuangan dan Locus of Control terhadap Kinerja UMKM", Jurnal STIE Bank BPD Jateng.

${ }^{12}$ Hery dan Domy (2012), "Faktor-faktor yang Mempengaruhi Kinerja Usaha Mikro Kecil Menengah (UMKM) Kota Madiun", Jurnal Ekomaks Universitas Merdeka Madiun.

${ }^{13}$ Sutrisno, Edi. 2009. Manajemen Sumber Daya Manusia Edisi pertama. Jakarta: Kencana Prenada Media Group

${ }^{14}$ ojk.go.id, diunduh, 10 september 2019

${ }^{15}$ OJK, http://indopos.co.id, diunduh, 10 september 2019

${ }^{16}$ htps://wwewpy 


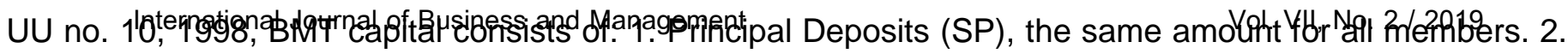
Special Principal Deposits (SPK), to get initial capital, so that BMTs can prepare and start their operations, this amount can be different for each founding member.

\section{The Government's Role in Developing SMEs by utilizing digital facilities}

Zulkhibri, Muhamed, $(2016)^{17}$, said, the Islamic financial services industry has a long way to go in increasing its financial inclusion in many Muslim countries because of the scale required and its relatively weak infrastructure.

Access to finance in Islamic countries is predicted by the specific characteristics of companies and factors of the level of the country's economy and non-economy. Financial inclusion reforms must focus on smallscale, introverted, and service-oriented companies that operate some distance from the center. ${ }^{18}$

\section{Previous Studies}

Zulkhibri, Muhamed $(2016)^{19}$, examines the relationship between financial inclusion and the Islamic financial services industry in Muslim countries Using qualitative analysis, finding that, most Muslim countries lag behind other developing economies in both respects, with the level of financial inclusion only $27 \%$. Cost, distance, documentation, beliefs, and religious requirements are some important obstacles. In addition, the level of Islamic microfinance is very limited, small by international standards; it accounts for about $0.5 \%$ of global microfinance, and does not have a cost-efficient service model. It was found that Islamic instruments to redistribute income such as waqf, qard-al-hassan, sadaqah, and zakat, could play a role for more than 40 million people, financially excluded for religious reasons, into the formal financial system. The Islamic financial services industry has a long way to go to increase financial inclusion in many Muslim countries due to the scale required and relatively weak infrastructure.

Asongu, et.al., $(2018)^{20}$, discusses the extent to which financial developments contribute to the development opportunities of low-income people and with information technology mechanisms, by reviewing 180 newly published papers to provide the latest information technology advancements in finance in inclusive development. Financial innovations that are maintained are based on three themes: (i) ruralurban division, (ii) women's empowerment and (iii) human capital in terms of skills and training. Financial instruments are articulated with case studies, innovations and investment strategies with special emphasis, including informal finance, microfinance, mobile banking, crowdfunding, microinsurance, Islamic finance, remittances, Payment for Environmental Services (PES) and Diaspora Investment in Diaspora Investment in Agriculture (DIA) agricultural initiatives.

Zhang, Xiaoqun, $(2013)^{21}$, The Internet Consumption Model was developed by integrating the theoretical construction of the Technology Acceptance Model (TAM) and Consumption Theory, intended to expand TAM by adding accessibility and affordability, two important factors that influence the diffusion of the Internet, also to expand Consumption Theory by adding two psychological factors to TAM - perceived ease of use of the Perceived Ease of Use (PEU) and perceived usefulness of the Perceived Usefulness (PU). Based on the Internet Consumption Model, cross-country empirical research was conducted to examine the relationship between income, Gini indexes, and internet diffusion curve patterns. This shows that developed countries have steeper diffusion curves on the Internet and shorter time lags than developing countries.

Wulandari, et.al., $(2016)^{22}$, highlighting the unique aspects of Islamic microfinance based on the experience of Baitul Maal Wa Tamwil (BMT) in Indonesia, Findings of the proposed Model include the characteristics of the poor in pre-financing, financing and post- microfinance products to be used as a reference for policy makers. This paper also found that each region has unique product preferences depending on the characteristics of the poor.

\footnotetext{
${ }^{17}$ Zulkhibri, Muhamed, (2016), Financial inclusion, financial inclusion policy and Islamicfinance, Macroeconomics \& Finance in Emerging Market Economies, Vol. 9 Issue 3, p303-320, 18p

18 Journal of Economic Behavior and Organization (2016)

19 Ibid

20 Asongu, et.al., 2018, Recent finance advances in information technology for inclusive development: a systematic review, NETNOMICS: Economic Research \& Electronic Networking; Vol. 19 Issue 1/2, p65-93, 29

${ }^{21}$ Zhang, Xiaoqun, (2013), Income disparity and digital divide: The Internet Consumption Model and cross-country empirical research.

${ }^{21}$ Wulandari, et.al., 2016, Unique aspects of the Islamic microfinance financing process, Humanomics; Vol. 32 Issue 3, p230-247, $18 p$

22 Jebarajakirthy, et.al., 2014, War affected youth as consumers of microcredit: An application and extension of the Theory of

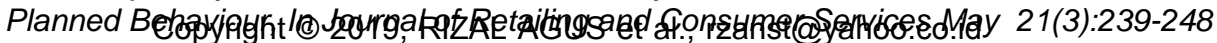




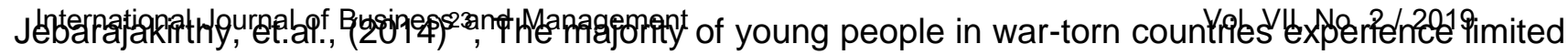
access to capital provided by traditional banking institutions. This research is to identify the Intention of Purchasing Micro Credit of youth affected by the war. The findings reveal that Positive Influence and Self Identity are predictors of Buy Intention; whereas Perceived Deterrents negatively affect Buy Intention. In addition, Entrepreneurial Desire seems to enhance the relationship between Self Identity and Purchase Intention. Entrepreneurial desires also directly influence purchase intentions. Based on these findings, we have suggested implications for theory and practice for effectively marketing microcredit to young people in war-affected areas.

Mohajerani, et.al., $(2015)^{24}$, explores the processes that enable social media interactions with the power of institutional entrepreneurship to create conditions for social change. More specifically we study adoption in Iran, new business practices and models that are more commonly seen in other contexts, and relate them to platform features and characteristics of a new generation of Iranian entrepreneurs. Drawing on our institutional logic theory conceptualizing this process as one transposition of logic in which the logic of dominant religion is challenged by market logic made possible by the reciprocal constitutional effects of human and material institutions, it is suggested that three main mechanisms support this process: the discovery of practice from an institutional context different, appropriation of foreign practices, and pre objectification

\section{METHODOLOGY \\ Stages of Research}

The first Stage is Creating a Model Construction; decompose the problem, by conducting a literature review, making questionnaires, in-depth interviews with experts, practitioners and conducting FGDs. After that the problems are constructed in a model so that it is easy to understand, then validate the model to one respondent who is considered more expert than the others to ensure the model is correct and can represent the problem under study. The second stage is to Quantify the Model, i.e. by applying it into the Super Decision software to compile a pairwase comparison questionnaire between nodes in the cluster in order to know which of the two is more dominant and how big the difference (on a scale of 1-9.5). After the questionnaire is completed and tested, a survey of respondents is then conducted to determine the priority of the cluster or element that has the most important influence on the problem, stage 3, Conduct Results Analysis, which is to quantify the questionnaire filled with inputting software, then determine the average the average value of each respondent's questionnaire answers, calculating the value of Kendall's coefficience as one of the measuring tools to calculate the rater agrement (agreement value) between respondents and interpreting the results. ${ }^{25}$

\section{Data Collection and Techniques Analysis}

This matter done by in-depth interviews, collecting field data, social researchers can use in-depth interviews / is open. Implementation and he observed to be repeated.$^{26}$ This study, using a list of questions as a guide in the field. Perform direct recording and using a recording for later re-recorded as a result of the interview

${ }^{27}$. This is done on two groups of experts from MSEs and BMT at Sumatera Utara.

\section{Focus Group Discussion (FGD)}

FGD conducted on 7 expert and MSE, to understand the problem, formulate a model of the problem, after being validated to two experts then construction research on cluster elements can be added or subtracted.

\section{Data Validity Testing}

Data declared in valid if there is no difference with the report is happening ${ }^{28}$. In this research, the credibility test used is to test the source triangulation. By checking the data obtained from the expert to see where the

\footnotetext{
${ }^{23}$ Mohajerani, et.al, (2015), Exploring the role of social media in importing logics across social contexts: The case of IT SMEs in Iran, In Technological Forecasting \& Social Change 95:16-31

${ }^{24}$ Mohajerani, et.al, (2015), Exploring the role of social media in importing logics across social contexts: The case of IT SMEs in Iran, In Technological Forecasting \& Social Change 95:16-31

${ }^{25}$ Rusydiana, Aam Slamet \& Abrista Devi, Analytic Network Process: Pengantar Teori dan Aplikasi, 2013

${ }^{26}$ Meleong, Lexy.2014. Metodologi Penelitian Kualitatif. Bandung. PT: Remaja Rosdakarya.

27 Bungin. Burhan. 2012. Analisis Data Penelitian Kualitatif. h.103, Penerbit Raja Grafindo Persada. Jakarta

${ }^{28}$ Sugiyono (2017). Metode Penelitian Kualitatif: Untuk penelitian yang bersifat: eksploratif, enterpretif, interaktif, dan konstruktif.

Bandung: Alfapsptght @ 2019, RIZAL AGUS et al., rzanst@yahoo.co.id 


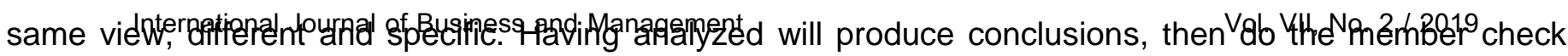
with the source data. Besides, it is done using interview data references that are supported by the record.

\section{Synthesis and Analysis \\ Geometric Mean}

Perform calculations of geometric mean to know the results of respondents' assessments and Determine the results of opinions in one group ${ }^{29}$. Questions (pairwise comparisons) of respondents will be combined to find out their consensus, this is a type of average calculation shows that a certain trends or value with the formula below: ${ }^{30}$

$$
\left(\Pi_{i}^{n}=1 a_{i}\right)^{1 / n}=\sqrt[n]{a_{1}} a_{2} a_{n}
$$

\section{Rater Agreement}

To measure the level of respondents' agreement $(\mathrm{R} 1-\mathrm{Rn})$ of problems that exist in one cluster, using the Kendall concordance coefficient tool $(\mathrm{W} ; 0<\mathrm{W} \leq 1)$. $\mathrm{W}=1$ shows perfect conformity ${ }^{31}$.

To calculate the value of $\mathrm{W}$, first, rank each answer and then add together.

$$
\begin{gathered}
\left(\Pi_{i}^{n}=1 a_{i}\right)^{1 / n}=\sqrt[n]{a_{1}} a_{2} a_{n} \\
R_{i}=\sum_{j}^{m}=1 r_{i, j}
\end{gathered}
$$

The average value of the total ranking is:

$$
R=\frac{1}{2} m(n+1)
$$

The sum of the squares of deviations (S), calculated using the formula:

$$
S=\sum_{i}^{n}=1\left(R_{i}-\bar{R}\right)^{2}
$$

So that Kendall's W is Obtained items, namely:

$$
W=\frac{12 s}{m^{2}\left(n^{3}-n\right)}
$$

if the value of $W=1$, it can be concluded that the opinion of the respondent has a perfect fit. however, when the value of $W=0$ or close to 0 , it indicates a mismatch between the respondents' answers or the existence of various answers ${ }^{32}$.

\section{Model Construction}

In order to build a research model (construction), the researchers conducted in-depth interviews with seven (7) experts who were considered masters of this problem. Based on literature review and in-depth interviews with seven experts and began with a literature review from a variety of reading sources (national journals and international), using network analysis analysts built using super decision software tools. The existence of feedback increases priorities derived from judgments and makes predictions more accurate. Therefore, ANP results are expected to be more stable.

Figure 1: Detailed research model formed after the construction phase of the model

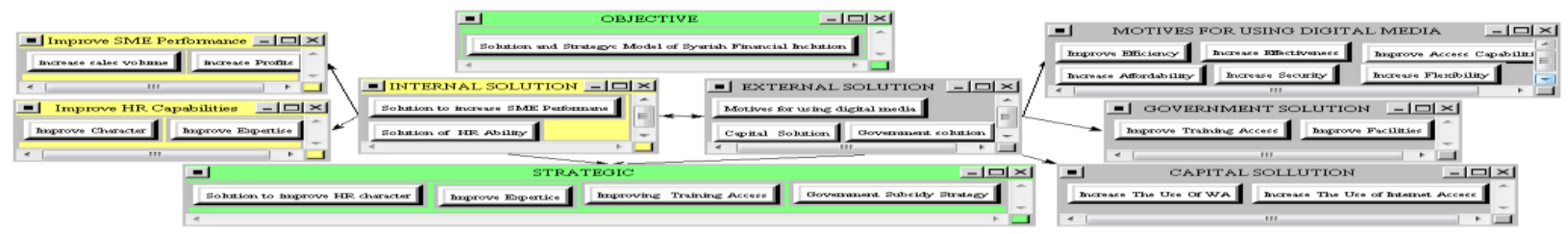

The above model explains that the purpose of the development of the model is to find effective solutions and strategies on the inclusion of Islamic finance by utilizing digital media for SMEs (case study of BMT partner MSEs in Deli Serdang Regency). There are 2 (two) main levels in this research model, namely the solution level and the strategy level. Solution level has two main sub criteria, namely internal and external solutions. Internal solutions have two sub criteria, namely MSEs performance and HR performance. External solutions have three main sub-criteria, namely motives for using digital media (BMT), BMT capital, and government. There are six (6) elements in the strategy cluster looking for an effective model of Islamic financial inclusion with the use of digital media for SMEs (case study of BMT partner MSEs in Deli Serdang District), namely, improving character, improving expertise, increasing training, and subsidizing facilities by the government.

\footnotetext{
${ }^{29}$ Saaty, T. L. dan Vargas, L. G. (2006). Decision Makng With The Analytic Network Process. Springer: United states Of America

30 Ascarya, 2011,"The Persistence of Low Profit and Loss Sharing Financing in Islamic Banking: The Case of Indonesia"review of Indonesian economic and business studies vol. 1 LIPI economic research center.

${ }^{31}$ Ascarya dan Yumanita, Diana, 2010,"Determinan dan Persistensi Margin Perbankan Konvensional dan Syariah di Indonesia" working paper series No.WP/10/04. Pusat Pendidikan dan Studi Kebanksentralan Bank Indonesia

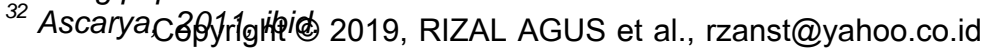




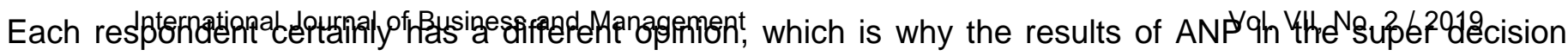
software present the results of the conclusion based on the average value (geometric mean) to determine the overall priority order and the results of synthesis for each respondent

\section{Analysis of Results of Cluster Synthesis Internal Solutions}

The first ANP results are internal solution clusters The graph below shows the priority conditions of the elements in the internal solution clusters according to the expert's view by showing the average results of all respondents.

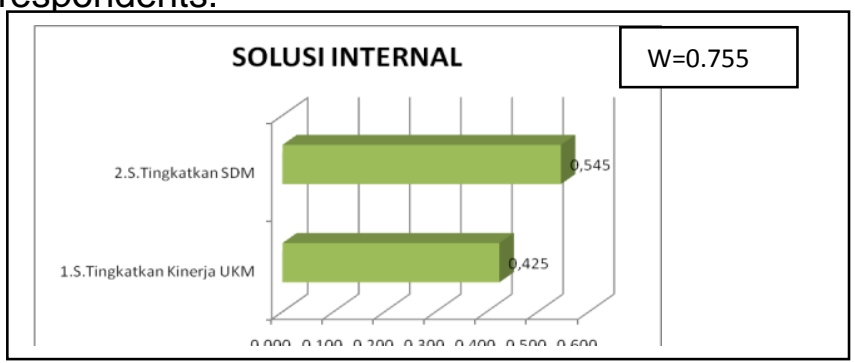

Figure 2: Results of the Synthesis internal solution Priority Based on the Mean Geometric Value

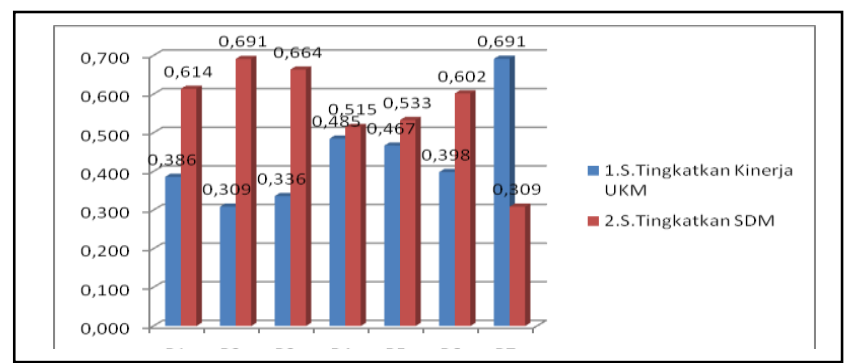

Figure 3: Results of the Synthesis internal solution Priority Based on the Value of Each Respondent Source: interview, data processed

The main internal solutions agreed by all respondents were: 1) solutions to improve HR (54.5\%); and 2) solutions to improve MSEs performance (42.5\%). To see the results of the priority synthesis per respondent, it can be seen in the picture above. The acquisition value of $\mathrm{W}$ (rater agreement) is equal to 0.755 or 75.5 high.

\section{Analysis of Synthesis Results, Cluster Solutions improve HR}

The solutions to improve the main HR agreed by all respondents were: 1) solutions to increase expertise $(56.9 \%)$; and 2) solution to increase character (34.5\%). Obtaining a W value (rater agreement) 0.592 $(59.2 \%$,$) means that the respondent's agreement level is quite high$

\section{Analysis of Synthesis Results, Solution Clusters Improve MSEs Performance}

The solutions to improve the performance of the main MSEs agreed by all respondents were: 1) the solution to increase sales turnover (49.2\%); and 2 ) the solution to increase profits $(43.8 \%)$, the acquisition of the value of W (rater agreement) is $0.500,(50 \%)$ shows the level of agreement of respondents is quite high,

\section{Analysis of Synthesis Results, External Solution Clusters}

The main external solutions agreed by all respondents were: 1) BMT capital solutions $(35.9 \%) ; 2)$ government solutions (35.4\%); and 3) the motive solution for using digital media for BMT (23.1\%), obtaining the value of $\mathrm{W}$ (rater agreement) 0.388 . $(38.8 \%$,) indicates the level of agreement of respondents is quite low.

\section{Analysis of Synthesis Results, BMT Capital Solution Clusters}

The main BMT capital solutions agreed by all respondents were: 1) solutions to improve the use of WA $(49.2 \%)$; and 2) solutions to increase the use of internet access $(39.1 \%)$. The result of obtaining the value of W (rater agreement) is $0.500(50 \%$,$) . shows the level of agreement of respondents is quite high.$

\section{Analysis of Synthesis Results, Cluster Motive Solutions for Using Digital Media}

Motive Solutions The main uses of Digital Media agreed by all respondents were: 1) solution to improve access capability $(17.3 \%) ; 2)$ the solution increases effectiveness $(15.8 \%) ; 3$ ) solutions improve affordability $(14.8 \%)$; 4) solutions improve security (13.9\%); 5) solutions increase flexibility (13.6\%); and 6) solution to increase efficiency (10.6 acquisition value of $W$ (rater agreement) 0.057 . (5.7\%,) shows the level of agreement of respondents is very low.

\section{Analysis of Synthesis Results, Government Solution Clusters}

The main Government Solutions agreed by all respondents were: 1$)$ solutions to improve training (44.5\%); and 2) solution to improve facilities (43\%). The diversity of the acquisition value of $W$ (rater agreement) is $0.510(51 \%)$ indicating the level of respondents' agreement is quite high.

\section{Analysis of Synthesis Results, Strategy Clusters}




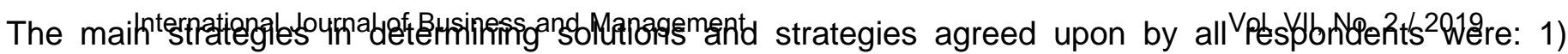
increase training $(25.6 \%)$; 2) facility subsidies by the government $(25.3 \%)$; 3 ) expertise improvement (23.4\%); and 4 ) increase character (20.1\%). the acquisition value of $\mathrm{W}$ (rater agreement) is $0.012(1.2 \%)$ indicating the level of agreement of respondents is very low.

\section{CONCLUSIONS}

From the research that has been done, several conclusions can be drawn namely, the main internal solution are improving MSE's HR, followed by improving performance, the main solution to improve HR's is improving expertise, followed by HR' character, the main solutions to improve the performance of MSE's is increasing sales turnover, then to increase profits. The main external solution is the BMT capital solution followed by the government solution and the motive solution for using digital media for MSE's -BMT. The main BMT capital solution is a solution to increase the use of WA followed by increasing the use of internet access. Motive Solution for the use of digital media namely, to increase access capability followed by increasing effectiveness, affordability, security, flexibility and efficiency. The main Government Solutions namely to improve training, followed by facilities. The main strategy in determining solutions and strategies agreed by all respondents is to increase training followed by government subsidy facilities, skills improvement and character building.

\section{RECOMMENDATION}

Some recommendations that can be given are as follows:

The need for the efforts of various stakeholders, especially decision makers to take priority steps and appropriate strategies to overcome the main problems faced by BMT

This study is expected to be able to help expand academic studies related to the use of digital facilities that are suitable for MSEs-BMT in improving its performance, and can help stakeholders as an effective input to solve problems appropriately.

For further research using the ANP method, it is recommended to be able to select the quality of participants who are experts in their fields.

\section{ACKNOWLEGMENT}

On this occasion, the author would like to thank the government who has supported funding to conduct this research, to the director of the Politeknik Negeri Medan who has motivated in completing this article, as well as to the chairman and all Research staff and Community Service Units (UPPM) who have supported the success of this research, the chairman of the accounting department and all those who cannot be mentioned that have helped the success of this research.

\section{DAFTAR PUSTAKA}

Ahmad dan Yohana (2012), "Pengaruh Kompetensi SDM, Kualitas Informasi Keuangan dan Locus of Control terhadap Kinerja UMKM", Jurnal STIE Bank BPD Jateng.

Ascarya, 2011,"The Persistence of Low Profit and Loss Sharing Financing in Islamic Banking: The Case of Indonesia"review of Indonesian economic and business studies vol.1 LIPI economic research center.

Ascarya dan Yumanita, Diana, 2010,"Determinan dan Persistensi Margin Perbankan Konvensional dan Syariah di Indonesia" working paper series No.WP/10/04. Pusat Pendidikan dan Studi Kebanksentralan Bank Indonesia

Asongu, et.al., 2018, Recent finance advances in information technology for inclusive development: a systematic review, NETNOMICS: Economic Research \& Electronic Networking;, Vol. 19 Issue 1/2, p65-93, 29p. https://doi.org/10.1007/s11066-018-9127-0

Bedjo Santoso, Khaliq Ahmad, The Financial Inclusion Model Based On Baitul Mal Wa Tanwil (BMT) Cooperatives And Community

Bungin. Burhan. 2012. Analisis Data Penelitian Kualitatif. h.103, Penerbit Raja Grafindo Persada. Jakarta

Buzzel \& Gale and Sultan, Export Market Strategy, Marketing Strengths and Export Performance: Empirical Evidence from Malaysia, ( Universiti Sains Malaysia, Glagrow DR.Osman Mohamad, Scholl of management, 1976).

Hassan, Abul, 2015, Financial inclusion of The Poor: From Microcredit To Islamicmicrofinancial Services, Humanomics; Vol. 31 Issue 3, p354-371, 18p. https://doi.org/10.1108/H-07-2014-0051 


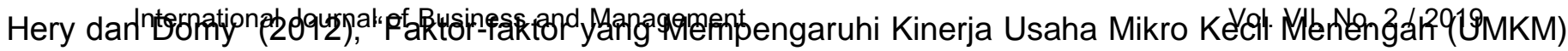
Kota Madiun", Jurnal Ekomaks Universitas Merdeka Madiun. https://doi.org/10.1016/j.jebo.2016.10.025

In Special issue on Islamic Finance, Journal of Economic Behavior and Organization December 2016132 Supplement:216-236

Jebarajakirthy, et.al., 2014, War affected youth as consumers of microcredit: An application and extension of the Theory of Planned Behaviour, In Journal of Retailing and Consumer Services May 21(3):239-248. https://doi.org/10.1016/j.jretconser.2014.02.003

Maulana, et.al., (2018), Factors influencing behaviour to participate in Islamicmicrofinance, International Journal of Islamic \& Middle Eastern Finance \& Management; Vol. 11 Issue 1, p109-130, 22p. https://doi.org/10.1108/IMEFM-05-2017-0134

Mohajerani, et.al, (2015), Exploring the role of social media in importing logics across social contexts: The case of IT SMEs in Iran, In Technological Forecasting \& Social Change 95:16-31. https://doi.org/10.1016/j.techfore.2014.06.008

Meleong, Lexy.2014. Metodologi Penelitian Kualitatif. Bandung. PT: Remaja Rosdakarya.

Rangkuti Freddy, Business Plan, Teknik Membuat an Bisnis \& Analisis Kasus, Jakarta: PT.Gramedia Pustaka Utama, 2001.

Rusydiana, Aam Slamet \& Abrista Devi, Analytic Network Process: Pengantar Teori dan Aplikasi, 2013

Safitri, Shariah Marketing Characteristics And Trust: Study On Customer Bmt In Malang, Indonesia, Russian Journal of Agricultural \& Socio-Economic Sciences; Dec 2016, Vol. 60 Issue 12, p74-78, 5p. https://doi.org/10.18551/rjoas.2016-12.09

Saaty, T. L. dan Vargas, L. G. (2006). Decision Makng With The Analytic Network Process. Springer:

United states Of America

Safitri, (2016), Karakteristik Dan Kepercayaan Pemasaran Syariah: Studi Tentang Bmt Pelanggan Di Malang, Indonesia, Jurnal Rusia IImu Pertanian \& Sosial-Ekonomi; Vol. 60 Edisi 12, p74-78, 5p

Santoso et.al., (2016), Determinants of Financial Literacy and Financial Inclusion Disparity Within a Region: Evidence from Indonesia, American Scientific Publishers, Volume 22, Numbers 5-6, May 2016, pp. 1622-1624(3). https://doi.org/10.1166/asl.2016.6706

Sugiyono (2017). Metode Penelitian Kualitatif: Untuk penelitian yang bersifat: eksploratif, enterpretif, interaktif, dan konstruktif. Bandung: Alfabeta

Sundaram (2019), A Review: Customers Online Security on Usage of Banking Technologies in Smartphones and Computers, Pertanika Journal of Science \& Technology;, Vol. 27 Issue 1, p1-31, $31 \mathrm{p}$

Sutrisno, Edi. (2009). Manajemen Sumber Daya Manusia Edisi pertama. Jakarta: Kencana Prenada Media Group

Wahyudi, Imam, (2015), Realizing knowledge sharing in strategic alliance: case in Islamic microfinance, Humanomics; Vol. 31 Issue 3, p260-271, 12p. https://doi.org/10.1108/H-10-2013-0067

Wulandari, et.al., (2016), Unique aspects of the Islamic microfinance financing process, Humanomics; Vol. 32 Issue 3, p230-247, 18p. https://doi.org/10.1108/H-09-2014-0062

Zhang, Xiaoqun, (2013), Income disparity and digital divide: The Internet Consumption Model and crosscountry empirical research. https://doi.org/10.1016/j.telpol.2012.12.011

Zulkhibri, Muhamed, (2016), Financial inclusion, financial inclusion policy and Islamicfinance, Macroeconomics \& Finance in Emerging Market Economies, Vol. 9 Issue 3, p303-320, 18p. https://doi.org/10.1080/17520843.2016.1173716

https://www.tribunnews.com/regional/2019/07/11/kemenkop

https://www.kemenkeu.go.id/publikasi/berita/microfinance-syariah, 8 september 2019

https://www.medcom.id/ekonomi/analisa-ekonomi/5b2VgYvb-babak-baru-bmt-di-indonesia, 8 september 2019

http://indopos.co.id, diunduh, 10 september 2019

ojk.go.id, diunduh, 10 september 2019

Peraturan OJK No. 76 /POJK.07/2016

https://www.viaempresa.cat/, 10 September 2019). 
